\title{
Female Genital Mutilation and Gender Politics in Modern Egypt
}

\author{
Hilary Burrage, Northwestern University
}

Maria Frederika Malmström, The Politics of Female Circumcision in Egypt: Gender, Sexuality and the Construction of Identity (London and New York: I.B. Taurus Press, 2016). 244 pp. Hardcover. \$115.00.

Heidi Morrison, Childhood and Colonial Modernity in Egypt (London and New York: Palgrave Macmillan, 2015). 176 pp. Hardcover. \$90.00.

Nefissa Naguib, Nurturing Masculinities: Men, Food and Family in Contemporary Egypt (Austin: University of Texas Press, 2015). 144 pp. Paperback. \$21.95.

Where to start? The challenges of reviewing three books about different aspects of a society and country, Egypt, which I have never had the opportunity to visit, all in the context of rapid and oscillating change at every level, are many. Indeed, some might suggest that these challenges are insuperable. I hope however that the inevitable constraints of such a context can be met by other aspects of this reviewer's experience: I am a sociologist with a very long-time interest in gender and its manifestations in many parts of the world; as a British citizen I am acutely aware of issues around colonialization; and I have researched and written about female genital mutilation (FGM) - designated "female circumcision" in the books under consideration-for almost two decades. ${ }^{1}$ I am also, for the removal of any doubt, Caucasian, and a committed western-style feminist.

The possible preconceptions necessarily declared, however, a much more critical challenge must be met. Is it possible to make sense in any meaningful way of independent publications which address, respectively, food and men, colonialism and childhood, and "female circumcision" — which, for reasons discussed later, I will refer to hereafter as FGM - and politics? The answer is I think “yes," but it's complicated. It is particularly through the lens of human rights and, more specifically, FGM, that I will consider these three differently thought-provoking treatises. The book by Malmström comprises over 200 pages of actual text, but those of Morrison and Naguib each offer just less than 130 pages. They also comprise different levels of evidence and analysis.

Nefissa Naguib is a professor of anthropology at the University of Oslo in Norway, but her book is intentionally written, as her editor asked, so that her "grandmother could read it." Nothing wrong with that, and it is indeed in most ways the easiest book to absorb. Like the two other books examined here it even has photographs of real people, something found perhaps more so in ethnographic 
texts than in various other disciplines.

The title of Naguib's book, Nurturing Masculinities, is, I suspect, intentionally ambiguous. Her focus throughout the text is mostly on that perennially important feature of anthropological examination, food, as she observes and reports on a group of men, residents of neighbourhoods around Tahrir Square-the location of turmoil during the January 25 Revolution of 2011 — and also living in the central downtown district of her childhood home, Cairo.

Naguib's focus is as much on how these men sustain their sense of masculinity in difficult circumstances, as on how these fathers sustain their families. It seems these two aspects of life are intertwined. The book is almost literally the tale of the inner-city Cairo butcher, baker and (to amend the historical expression, candle sticks now being obsolete) coffee-drink maker. As Naguib tells it:

My concept of 'nurturing masculinities' has been developed through exploring men's relation to food, and it builds on the growing body of literature on "lived masculinities" (Inhorn 2012) which unsettles the dominant trope of relying on domination and patriarchy when discussing Middle-Eastern men ... These are stories of men who care deeply about their families. We hear them speak about extraordinary economic hardship, politics, and activism ... we feel their desires to feed their families well and often.

There is material in this book to which almost any reader can relate- the reporting of real-life problems like food on the table-but there is also an overarching invitation to see these preoccupations in the context of how achieving such everyday ends reinforces the sense of the subjects of these pages that they are real men. Procuring nutritious food and engaging in some aspects of domestic and sometimes public life is both satisfying and a source of pride for such men. It is interesting, too, that food plays an important part for men in some political and welfare activities in the public sphere. One specific and fascinating example of this is Naguib's accounts of young men, members of the Muslim Brotherhood-founded in 1928 by primary school teacher Hassan al-Banna-and how their community work during the 2011 uprisings in Tahrir Square and elsewhere was significantly around the price of food and also the direct provision of food for protesters. At one stroke bread became for such Egyptian men both a symbol of oppression and a means to protest.

This provision of bread reflected the general "food activism" of the Brotherhood, with its emphasis on "moral cosmologies" and the imperative to help those in need. Food activism, in Naguib's formulation, demonstrates how for these men religion operated within the broad parameters of morality, practice, controversy and convention. Naguib reports for instance that in 2011 the Brotherhood argued 
in the media that food justice comprised an element of their outreach to all Egyptians_-an outreach which, it may be observed, served their recruitment strategies well.

As one young Brother explained, contrasting his own approach with those of the older men, "I combine my Muslim faith and my energy in mobilizing against food injustice and for food sovereignty." For this young man, acting out his faith via food justice was a progressive matter; but on another wider level it was also one which, significantly during this troubled time, did no harm to signing up new followers. Food activism, as both a spiritual and welfare matter, created a connection between those receiving and those providing the food. Food, and especially bread, has throughout history been symbolic as well as necessary. In Naguib's account of recent Egyptian troubles, food has had special significance for Egyptian men, and perhaps especially for nationalists. It symbolized the struggles of ordinary people to procure nourishment and to maintain their dignity during times of scarce resources and, in their eyes, imperialist oppression.

Similarly focused on the struggle against nationalism, colonialism, and imperialism, Heidi Morrison invites us to consider these relationships through an examination of children and two hundred years of education policy in Egypt. Morrison is an historian at the University of Wisconsin, La Crosse. Her book, a publication under the umbrella of the Palgrave Studies in the History of Childhood, comprises a pioneering examination of the modern history of childhood in the Middle East. Like Nefissa Naguib, Morrison's text has a very particular focus, this time the emergence and associated influences of the notion of childhood as an element in the construction of modern Egypt. It makes for a fascinating read, opening this Westerner's eyes at least to disparate ways of looking at often seemingly self-evident assumptions. Children, Morrison observes, are always in the crossfire of forces that shape history. Actors in the margins of power often reshape society. Evidence drawn largely from feminist research suggests, for instance, that the Industrial Revolution might not have unfolded in Britain as it did in the absence of children's participation. This role in national modernization has however has played out for non-Western countries in somewhat different ways.

To use Morrison's own words, her book “focuses on general changes in the [Egyptian] literate classes' thinking about childhood, less so than on the concrete, institutional transformations these changes generated." In pursuit of this focus she alerts us to numerous examples of gendered difference, to realignments which acknowledge both the emotional perceptions and experience of childhood, and to the growing understanding in Egypt that childhood has a status independent of "pre-adulthood." That changed, independent status, Morrison suggests, can become a vehicle for bringing the state and its citizens into constructive alignment, where before there was little social and communal context beyond the family for most rural and/or poorer Egyptians.

But there is more to the concept of childhood we are invited to consider 
than simply a shift from the private to the public sphere, from ideas of children as pre-adults who require instruction about mature behaviour, to the notion of childhood innocence and vulnerability. Morrison reminds us, perhaps to our surprise, that it was not until 1989 that, via the United Nations Convention on the Rights of the Child, children became the subject of rights rather than objects of concern.

Nonetheless non-Western regions of the world have inevitably developed conceptions of childhood that sit alongside the Western world, rather than embracing that model wholesale. Whilst the Western model of childhood sits within the traditions of the Enlightenment, Romanticism, and industrialization, that of nations such as Egypt resides within a heritage of colonial resistance and Islamic tradition. Whilst the British at home were taking forward ideas about individual autonomy and human rights, including those of children, they were less enthusiastic about the same ideas being applied to children in Egypt, especially less advantaged ones. Child labour in Egypt was required to work the cotton mills for example, just as it had been required previously in the United Kingdom. This was surely acceptable, the colonialists claimed, because Egyptian children matured earlier than British onesexcept that perhaps actually they didn't. But in any case, came the argument, poor and illiterate Egyptian children weren't really in need of education. Best leave that to the privileged classes, Egyptian and colonial British alike.

The direct colonial influence on who received an education and how childhood should be regarded was not, however, the sole guide to views of childhood in Egypt during the twentieth century. Another critical influence was the emphasis on group, as opposed to individual, rights. Yes, in part this resulted from the traditional view of the child's worth to the nation, but it was also prompted by the nationalist reaction to imperialism, to a collective rejection of that oppression. As such, the positioning of childhood in the context of the value of pre-adults to the nation should not, as western scholars and children's rights activists often suggest, be attributed to Islam, albeit Islamic constructs do admit an inherent lack of space for the individual. In this case, however, remaining ideas in Egypt of the child as inherently part of the collective, not as someone with individual rights, have resulted mainly from colonialism and nationalist resistance thereto.

It is important, in what Morrison offers us, to acknowledge the differing historical and social foundations for ideas about childhood. Perhaps, to experienced scholars and observers in Egypt, these differences are easily recognized, but to some embedded in Western ways of perceiving children these diverse roots need to be spelled out, in all likelihood for many reasons even above and beyond the academic study of "childhood" as such. These differences become particularly noteworthy, for instance, in the context of contemporary Egyptian politics and the turmoil of the decades which preceded them. As with Naguib's book, that which we fail to note about the habitually unstated assumptions which shape the behaviour of nonWestern individuals and groups will give rise to misunderstandings of noteworthy, sometimes substantial, significance. What we witness is inevitably perceived through 
the lens of what we have previously known, which is one of numerous reasons why social scientists' and anthropologists' translational analysis of understandings and customs in societies and communities unlike our own has especial value.

But to specifics. Morrison focuses quite heavily — and rightly as a historian-on questions of how Egypt, as a state-identified Islamic country, sought to develop an education system which would convert small community members into adults fit to serve the nation state, acquiring "western" or modern knowledge and skills set within a separate and distinctive context; but she also seeks to untangle the class and gendered aspects of these transitions.

In considering these factors of class, gender and, of course, ethnicity/nationality Morrison draws on many strands of published material including official documents and more diverse sources such as publications for children over the past century and more. Commentary on these books and magazines of itself makes for an interesting read; and, unsurprisingly, her analysis leads us to see that expectations for Egyptian women and men, mothers and fathers, girls and boys, were and are different. The various strains between traditionalism and modernity, imperialism and nationalism, faith-Islamic, Coptic etc_-and secularism have, however, ensured that "progress" is not linear, nor have developments in each of these aspects necessarily run in parallel.

These variations can all be seen as aspects of the professionalization of child care, health care, education and so forth. The changes arose at the same time as the distinctions between "women and children" (previously set in historical, rural settings, now in a complex urban context) have become more marked; but still they demonstrate overlap in some respects. Indeed, in this regard Naguib's work comes again into play. The men in Cairo whom she considers in her research similarly demonstrate modes of reconciliation between their strong sense of gendered identity, masculinity, and their engagement in family life, and between their impoverished conditions and their feelings of national pride.

There is no doubt that Heidi Morrison has produced a well-researched, readable, and scholarly book which will inform and trigger greater concern to explore the important issues she examines. We can quibble about the sometimes takenfor-granted references to "intellectuals" and "elites" — as a sociologist I would have liked to know more about how she defines these groupings and why. Likewise, the issues of land ownership-who may or could own it, and under what circumstances? - would be interesting to explore further; but we get the idea anyway.

While educational opportunity is by no means open to all, and Egypt still has many fundamental challenges to face, this text has much to offer academics, politicians and policy makers. In one particular, however, I remain bemused. Why is the connection between the genital cutting of both boys and girls not central to examination of authoritarian behaviours and perspectives in regard to children? Early in the book (11) Morrison refers fleetingly to the age of seven being when boys are circumcised; and many pages later (87) she tells us in specific detail about 
the factors which determine in traditional thinking the readiness of a child for adulthood and arranged engagements or even non-consensual marriage- first menstruation for girls and first nocturnal emission for boys. The consequences of what child "marriage" means, especially for girls, are also explored. A little further on in the text (94) the work of Nawal al-Sa'dawi (b. 1931) is brought into play, recording that writer's recollections of the views of her father-girls are worth only half the worth of a boy, her brother was given twice as much pocket money, etc. Then, on page 114, we are introduced to an earlier pioneer of women's rights, Huda Sha'rawi (1879-1947), noted as one of the very first women to refuse the veil, a protester of the ancient custom of harem-women remaining effectively prisoner at homeand founder in 1923 of the Egyptian Feminist Union, a major vehicle in the rising feminist sentiment in Egypt.

But where is the acknowledgement of female genital mutilation? Egypt is thought by many to be where FGM was first introduced some three thousand years ago, as a means of ensuring female slaves did not disrupt their work by having babies, and/or as a way to verify the identity of fathers in social circles where inheritance was important. Wives of wealthy and powerful men, it is said, were sewn up when their men went away, and cut again when husbands returned. The evidence that FGM originated in Egypt so long ago is weak but the belief is widely held, and certainly Egypt is now known to have one of the very highest incidences of FGM anywhere in the world. The "procedure" is usually carried out around the time of puberty and by tradition signifies the transition to womanhood and "purity," or virginity, in preparation for marriage. It is recognized worldwide as a harmful traditional practice, and as a referent to custom rather than to religion, having existed even well before the founding of any major faith —a fact reflected in the reality that FGM is known to be practised by both Muslims and Coptic Christians in Egypt. Both male circumcision - male genital mutilation/MGM-and FGM are critical signifiers of custom and heritage in traditional communities such as that which Morrison examines in the present text.

Further, Nawal al-Sa'dawi, whose account of childhood in Egypt is mentioned above, became an internationally respected physician, known especially for her writing on the imperative to eradicate the scourge of female genital mutilation. For al-Sa'dawi even imprisonment has not reduced her commitment to this and similar issues, just as her campaigning predecessor Huda Sha'rawi could not be silenced in her protests against the veil and other restrictions on women's freedom.

Given these considerations, it is difficult to see why FGM—and MGM; after all, both are inflicted on children—does not feature in Morrison's discussion of the authoritarian nature of Egyptian childhood and the ways in which traditional understandings are upheld via overt nationalism. These customs - they are not "cultures"- are intended directly and overtly to impress upon victims the reality of their inescapable subjugation and conditional dependency, and FGM especially is a consequence of economic forces; girls are by tradition chattels to be traded between 
fathers and husbands.

FGM and child, early, and forced marriage (CEFM) are by any measure patriarchy incarnate, the literal imposition of men's will on women and girls' bodies, and these traditions are acknowledged to be widely practised in Egypt. It is very odd therefore that these harmful traditional practices were not placed centre stageand in the case of $\mathrm{FGM}^{2}$ were completely passed over-in an otherwise comprehensive overview of childhood and "nationalist vs modern" communities in that country.

The above points take us neatly to the third book under consideration. Maria Frederika Malmström's The Politics of Female Circumcision in Egypt, published in 2016, comprises largely a thorough report of her ethnographic research in downtown Cairo. Her research aimed to explore, via self-reported experiences, the views and understandings of women in that location about FGM, with a particular focus on how it may have influenced their sense of themselves and their identity.

Morrison, in Childhood and Colonial Modernity in Egypt, ends her book with the words "The study of the history of childhood in Egypt and the Middle East more generally, has a long way to go. The smallest voices are calling out for attention" (127). Likewise, Malmström concludes her work by reminding us that "This book has tried to make room for less dominant voices in the local, national and global campaigns against FGM/C (sic) and the politics of the female body: those of women as actors" (206). The objective for each of these authors, employing largely ethnographic techniques, has been to "speak for" (doubtless they would say, quite legitimately, "via") the voice of those they perceive to be voiceless.

But this is where I start to struggle. My discomfort probably lies to an extent in the fact that I am a sociologist, whilst our colleagues-for respected colleagues in many ways they must be-on whom I am reporting are historians and/or anthropologists. We all have a part to play and we all choose our disciplines according to our predispositions; but even so, I find it increasingly difficult to become engaged in research about "the voiceless" which stands apart from praxis. My original professional studies concerned the sociology of science and knowledge, so the question marks around "why?" in research are for me always sharply defined. Why do we want to know? Via what perspective is there a problem to explore? Who are we finding this out for?

Naguib and Morrison examine situations which shine, for some of us at least, new light on the focus of their research. Naguib seeks, successfully, to challenge the Western stereotype of ordinary Middle Eastern men as disengaged from the domestic sphere. Yes, we find they still operate within very gendered frameworks, but we learn more than we may have known before about how these men, in a traditional, significantly unprivileged context, whilst also reasserting their masculinity and status, are nonetheless able through the provision of food to care proudly and warmly for their families. It is useful even for those on the outside to understand this better, at a time when international and national situations are 
volatile. We are here observing real human beings minus the Western stereotypes which predispose a lack of empathy or respect.

Morrison too invites us to reflect on an aspect of Middle Eastern/Egyptian society which few in the West may consider. We may well be aware of and regret the damage that imperialism and colonialism have caused, but our knowledge of its perception by generations of Egyptian children and their parents, and of the influences which have shaped developments in their education systems, is likely to be scant. Indeed, the same may even be true for many Egyptians in position to influence positive change.

It is deeply worrying to learn that even now many Egyptian children receive little education other, perhaps, than the rote learning prescribed by Islam. It is not our business as external visitors to pronounce on whether religious teaching is helpful — no doubt many in Egyptian communities value its cohesive influencebut every one of us can be concerned if the many young people of Egypt are still disadvantaged by the colonial conceits and greed of our forefathers. How to address this historical mistreatment is another matter, another time, for careful thought, but awareness of the challenges as some in that country perceive them is a first step.

Regretfully, I am less certain that Malmström's meticulous research takes us very far forward. The introductory material is comprehensive within the parameters she sets out, and her work is well reported and carefully thought out; but I remain to be convinced that, as I believe these days is necessary, it has all been set to good use. Put bluntly, there are already many texts that take the relativist position on the terminology of female genital mutilation, or "cutting," or "circumcision," or whatever other nomenclature you might select. In her introduction Malmström does address the issues around euphemisms - are we using "softer" terms which fail to describe the seriousness of FGM? - and she respects the use of "FGM" and "FGM/C" in official documents. Nonetheless, routine use of the term "female circumcision" can be indicative of a mode of conceptualization which many of us have now moved beyond. ${ }^{3}$

Yes, of course it is polite and respectful to use in personal conversation the term adopted by the narrator, but then there is a great divide: almost all anthropologists, especially those writing in English-Americans, Norwegians and Swedes, Britons, etc.- - prefer tellingly to use one or more of the "C" words-circumcision or cutting. Many others, wherever possible in formal use, have now adopted the "M" word-mutilation. Some of this divide reverts back, as Malmström does, to critiques of Fran Hosken, the determined but barn-storming Viennese-American pioneer of efforts to eradicate what she insisted be termed "FGM." " But Hosken died over a decade ago, in 2006, and it is surprising that she be cited as the most significant advocate for current terminologies.

And how strange, too, that the terminological recommendations of (medical) Dr Morissanda Kouyaté, head of the Inter-African Committee on Traditional Practices Affecting the Health of Women and Children (IAC), are not in evidence. 
The $\mathrm{IAC}^{5}$ is, after all, concerned with Africa, a continent which includes Egypt, represented as are other nations by its own committee on that Committee. The IAC, speaking as female leaders of African countries, has been influencing action to end FGM since 1986. Dr Kouyaté and his colleagues have long been firmly of the opinion that FGM is "mutilation":

many forms of unfounded justifications are put forward: women's cleanliness, purity of the female body, religious prescriptions, ritual passage to a superior social level, self-control, family honour, etc. The colour of the cast does not change the fracture. Regardless of the names and the forms given to FGM, the practice will always remain what it is: mutilation. ${ }^{6}$ [emphasis in original].

In fact, every one of the "unfounded justifications" which Kouyate lists above is competently and thoroughly considered in Malmström's book, and that is something all of us can appreciate.

For all that Egypt may well be the very first location where FGM was practised, that nation, as Malmström repeatedly emphasizes, has been slow to acknowledge and understand how and why FGM presents in the various Egyptian communities. Her painstaking ethnographic research shines a light on the beliefs and actions of Muslim women and, to a lesser degree, also on those who seek to provide their faith, pastoral and health care who now find themselves in the less privileged parts of Cairo. Most of the older women come from rural traditions; some of the younger ones are graduates.

Malmström is careful to remind us that what she reports applies only with any degree of confidence to those with whom she engaged-which means we learn little about Coptic Christians or, indeed, about wealthier families-but the complexity of the understandings she shares is illuminating. For instance, not only are the views and experiences of young and older women alike related in stark detail, but also woven expertly into the narrative are the parallel themes of moral sexuality, the bearing of pain and suffering, the meanings of motherhood, child and early or forced marriage, and even the rituals of defloration - within living memory a physical "operation" actually performed and observed by close family_and of regularly repeated depilations. And, beyond that, we also discover much about the multi-layered significance attached to everyday routines, in the kitchen and elsewhere-all of which chimes very well from another angle with what we learn via Naguib's work on food.

The work by Morrison chimes too with Malmström's thesis. The potency of the nationalist cause in Egypt, right up to the present, is presented as bolstered by the perceived political domination of imperialist/colonial forces externally and autocratic/military forces nationally. In such a context the path to "modernization" is rarely linear. The alienation and felt powerlessness of those towards the bottom 
of the pile provides rich fuel for the nationalist cause. And often one expression of that cause is a trend towards reverting to old "customs"-including, of course, FGM.

The detail of Malmström's depiction and analysis of these matters is impressive. She begins by telling us about a live TV relay during the 1994 International Conference on Population and Development of the "circumcision" of a 10-yearold girl in central Cairo, and of the denial just before that event by then-President Hosni Mubarak and his health minister that FGM was still a problem in their country. We gather from Malmström's account that in their own terms the denials of these politicians were valid-FGM is not acknowledged, let alone observed, in the public sphere, and especially not by men.

Needless to say, many across the world were shocked by this exposé, and very many in Egypt itself saw it as a direct-albeit apparently unexpected by the Danish film-makers_-attack on their nation's honour and sense of propriety. Not only was the physicality of this direct filming unacceptable — a sentiment many would still share-but it was a gross breach of the requirement in Islam for silence on some, especially intimate, matters.

From this shocking start Malmström moves us on to other deeply uncomfortable questions: How do women manage to maintain their personal faith, integrity, and honour whilst also continuing with activities like FGM, hymen repair, abortion, etc., which the state has banned? How is the marked trend towards the medicalization of FGM explained in a country which, following the death of a twelve-year-old under the mutilating scalpel, and after many legal vacillations-usually in response to foreign pressure-made it illegal in the clinical context, as well as when done by dayas, or traditional birth attendants (TBAs)? And so forth. All important and, indeed, very interesting matters.

It is, however, when we go to these wider issues that I start to feel uncomfortable. Malmström is quite clear that she writes from an anthropological and ethnographic perspective, and that is as we would expect. But when she examines matters other than those directly concerned with the women whose views she seeks, there is to my mind a lesser level of stringency and perhaps a glossing of some important realities. One example: on various occasions we learn of women who imply or actually say "they took it (her clitoris) all away; nothing is left." To report this as a fact - the woman says it, despite the reality that such complete excision would be impossible - is fine; but to draw conclusions from that fact alone about her capacity to formulate an informed, rational response is less so. I could not find any reference anywhere in Malmström's text to the medical, real, fact that the clitoris is quite a sizeable organ within a woman's body, as well as visibly external to it. That the woman concerned was correct in her understanding about complete removal is impossible; and so, too, therefore are conclusions by the author based on comments about sexual response which draw on that belief.

More importantly, there is in this text scant reference, let alone precise re- 
porting, on the present-day reason so many medical experts and others in public service are determined to make FGM history. Perhaps in times past there was a political and "missionary" element to the message, but now the emphasis is firmly on the ways in which FGM forecloses girls' and women's prospects-we read a little about this, albeit mostly in passing, as we should have in Morrison's book as welland on the damage to the health of both the girl-woman herself, as well as to her future offspring.

That these women have lost many babies is fully acknowledged as "suffering," which it surely is, but the medical fact that FGM may have contributed to the high levels of infant mortality is not considered. If it had been, perhaps the fervour of those in Egypt and beyond who seek to stop FGM might be clearer. Instead, we are presented only with the tensions between "modern" professional, political, and international pressures towards eradication, versus the values and beliefs of the women in the study.

Malmström is, I think, right that the same rationale fits both the continuation of FGM in Egypt, and amongst some younger Egyptian women, the desire to abandon FGM. By their own lights each is seeking autonomy and control over their own bodies.

But then we need to go beyond that. The eradication of FGM is necessary not only for reasons of human rights-yes, a contested issue in this context-but also because the abandonment of FGM goes hand in hand with healthier women and children. And good health, not least in a country where such a large number of its population is very young, is critical to the effective conduct of both the personal family locus, and at wider levels of economic functioning.

In short, we know that women living under considerable duress draw status and comfort from their very real suffering; but the challenge is to find better ways than harmful ritual to accord them status. That is what many who work to eradicate FGM are trying now to do. The days of imperialist condescension are generally well past. But this approach is lost in Malmström's account. She often sees only stereotypical "interventionists," politicians, and again, as mentioned before in this review, "elites."

In the course of her book Malmström examines a number of situations in which her academic or professional status sits uneasily with her personal connections in the field. She is absolutely right to do so. When is it okay to offer sympathy as well as attention? Is it right to press for painful recollections? And-adding my own question, unanswered in Malmström's text - should inaccurate beliefs about the physical facts of the clitoris be tactfully corrected?

For me the answer to all these dilemmas is generally yes, especially if the material garnered is to be put directly to good use in reducing further suffering or concerns. Unfortunately, that application of the material presented is what seems to be missing. Instead, unconvincing straw (wo)men-stereotypical old-style "interventionists" - have been constructed, against whom Malmström then sets her 
case. I would have preferred either that the carefully collated observations in this book were left as just that, acknowledging the ethical dilemmas but with no un-nuanced reference to others; or that the book finish with recommendations for further policy and action to address problems, drawing on current evidence of local and global good practice.

Perhaps I am being harsh about Malmström's meticulously constructed thesis. Nonetheless, I am convinced that in matters such as FGM and child marriage there is an over-arching responsibility for researchers, not least as fellow human beings, to try where we can to make things better. We are obliged to go the extra mile. It is not enough to acquire ethnographic data and simply set it against historical practice, or to surmise what will happen later on. We must be willing to engage actively in praxis as well, to dare to suggest what we judge might be the next practical, policy and perhaps political/legal steps in the difficult path towards eradication and a better life for those whom we ask to share their lives with us.

Each of the texts considered in this review has considerable merit. We can and should learn a lot from them. Singularly and together these books take us quite a way into the worlds of women, men, and children in colonial and now modern Egypt. They deserve to be read. Malmström, Morrison, and Naguib each set agendas for further consideration which will help considerably in further ethnographic research, and each by happy coincidence informs the others as we move forward. From each of them we in the West can gain important insights into the current troubling situation in Egypt, and how and why these problems have arisen.

I hope, however, especially in the examination of harmful traditional practices such as FGM, that in future we will see a more cross-disciplinary approach ${ }^{7}$ which, for clarity, goes way beyond the much-heralded and to my mind over-rated and often thereby leaderless "multi-agency" positioning we see so often in programmes to eradicate FGM.

Every academic discipline has its own methodologies and emphases, but none of them encompasses fully the realities of our modern-day world. When we are dealing with current global issues like FGM and CEFM we must at a minimum ensure our reports take the reader to accurate and up-to-date literature, policies, and approaches in disciplines parallel to our own. That is the very least we can do in return for the trust our field respondents place in us.

\author{
Hilary Burrage \\ www.hilaryburrage.com
}




\section{NOTES}

${ }^{1}$ See Hilary Burrage, Eradicating Female Genital Mutilation: A UK Perspective (Abingdon and New York: Ashgate/Routledge, 2015); Hilary Burrage, Female Mutilation: The truth behind the horrifying global practice of female genital mutilation (London, Sydney, Auckland: New Holland Publishing Pty Ltd, 2016).

${ }^{2}$ For a summary of the issues around female genital mutilation see Hilary Burrage, accessed October 10, 2017, "What is Female Genital Mutilation? An Introduction To The Issues And Suggested Reading," https:// hilaryburrage.com/2016/04/01/female-genital-mutilation-an-introduction-to-the-issues-and-suggested-reading/.

${ }^{3}$ Hilary Burrage, et al., accessed October 10, 2017, "Statement on Female Genital Mutilation (FGM): A Feminist Statement on the Naming and Abolition of Female Genital Mutilation," https://statementonfgm.com/.

${ }^{4}$ Hilary Burrage, Female Mutilation, 132. See especially Tobe Levin's narration on that page of Hosken's work.

5 "Inter-African Committee on Traditional Practices," accessed October 10, 2017, http://iac-ciaf.net/.

${ }^{6}$ Morrisanda Kouyaté, "Preface," in Burrage, Female Mutilation, 6.

${ }^{7}$ See Hilary Burrage, "Cross-Disciplinary, Cross-Purpose: The Muddles Of Multi-Agency Working," accessed October 10, 2017, https://hilaryburrage.com/2012/10/01/cross-disciplinary-cross-purpose-the-muddles-of-multi-agency-working/. 